\title{
Problem-based learning: Its effect on higher-order mathematical thinking skills in terms of student's initial abilities and mathematical beliefs
}

\author{
Dion Aris Simanjuntak ${ }^{*}$, Makmuri ${ }^{1}$, Wardani Rahayu ${ }^{1}$ \\ ${ }^{1}$ Universitas Negeri Jakarta, Indonesia \\ $₫$ dionarissimanjuntak@gmail.com
}

\section{Article Information}

Submitted Oct 26, 2021

Revised Dec 27, 2021

Accepted Dec 28, 2021

\section{Keywords}

Higher-Order Mathematical

Thinking Ability; Problem Based

Learning; Initial Mathematical Ability.

\begin{abstract}
The higher-order thinking ability of students in Indonesia is still in the low category. This research aims to see the effect of the application of a problem-based learning model on higher-order mathematical thinking skills in terms of student's initial abilities and mathematical beliefs. This research uses a quasi-experimental design with a Non-Equivalent Control Group Design. Data on students' higher-order mathematical thinking skills were taken using a test instrument. This research was conducted at SMP Negeri 27 Jakarta with a total of 165 students obtained from cluster random sampling. Based on the analysis of the three-way ANOVA test, it was found that the problem-based learning model had a positive effect on students' higher-order thinking skills. Problem-based learning model gives better results than conventional learning models. This also applies to students with the initial ability and mathematical beliefs in the high category. Problem-based learning can be an alternative for teachers to improve students' higher-order mathematical thinking skills.
\end{abstract}

\section{INTRODUCTION}

In Indonesia, students' higher-order mathematical thinking skills are still low (Purbaningrum, 2017; Ramadhan et al., 2020). When faced with math problems at a higher-order, students tend to be unable to connect and manipulate (Albay, 2019), and transform the knowledge and experience they already have to think critically and creatively in an effort to make decisions and solve problems in these situations (Hwang et al., 2020).

The low level of higher-order mathematical thinking skills of students shows that around $8.33 \%$ of students have difficulty in understanding questions, $15.59 \%$ in transformation, $32.53 \%$ in process skills, and $1.34 \%$ in mathematical encoding when faced with questions that require a higher level of analysis (Hadi et al., 2018). Tanudjaya \& Doorman, (2020) also stated that only about $1 \%$ of students in Indonesia can imitate mathematically complex situations when working on problems that require higher-order thinking skills. The presentation of these data shows that students' higher-order mathematical thinking skills are still low.

As is known, higher-order mathematical thinking skills refer to students' ability to perform complex thinking related to procedural and conceptual knowledge (Volk et al., 2017). Therefore, in mathematics, separating procedural and conceptual knowledge is not recommended even though it will have an impact on the development of student knowledge (Rittle-Johnson \& Schneider, 2015). Heong et al., (2012) revealed that higher-order thinking skills are very important for students because they can be used as an effort to train students to be able to think critically and creatively before entering the working world. Therefore, higher- 
order mathematical thinking skills are of course very important for students. Internal factors that are strongly suspected to influence this low ability are the initial abilities and mathematical beliefs of students.

Initial ability can be everything that students already have regarding material that is a prerequisite for studying further material that is continuous (Firmansyah, 2017). Good or bad student learning outcomes are determined by their initial abilities (Astuti, 2015; Hevriansyah \& Megawanti, 2017; Purwaningrum \& Sumardi, 2016). Several previous studies also concluded that students' initial abilities greatly affect communication skills (Nurmantoro, 2017) and students' understanding of mathematical concepts (Astriani, 2017). This is the reason why researchers want to see the effect of this variable on students' higher-order mathematical thinking skills. Not only that, but Mathematical Belief also needs to be observed its effect on students' higher-order thinking skills.

Mathematical Belief is important in learning mathematics. Learning something without having faith in what is being learned becomes meaningless learning. The higher the mathematical belief that students have, the higher their learning achievement (Isharyadi, 2017). This makes mathematical belief an important variable that needs to be observed in the learning process. However, several studies also show that students' mathematical beliefs have no effect on students' mathematical communication skills (Syarifah, 2017; Syarifah \& Firmansyah, 2016). Thus, it is necessary to study more deeply how influential this variable is on students' higher-order thinking skills.

In relation to higher-order mathematical thinking skills, of course, the teacher's role is also to be able to guide students to have better higher-order mathematical thinking skills. Teachers' understanding of higher-order thinking was able to improve students' higher-order mathematical thinking skills and help students to solve problems with more difficult levels (Abdullah et al., 2016). Not only that, but the facts in the field also state that teachers already understand the importance of students' higher-order thinking skills and teach them using various innovative learning models (Seman et al., 2017). Based on the data presented by several researchers, the low level of higher-order mathematical thinking skills of students can be overcome by involving learning models that are in accordance with student needs so that students have better higher-order thinking skills. One of the learning models that are thought to be able to improve students' higher-order thinking skills is the Problem Based Learning model (PBL).

The PBL model is expected to improve students' higher-order thinking skills because the PBL learning model focuses on students being more active in asking, analyzing, synthesizing, interpreting, concluding, reasoning, applying, and using intuition in creativity (Majeed et al., 2021; Seibert, 2021). The PBL model also involves students to conceptualize, prioritize problems, identify what is known and what is not known, test assumptions, assess different points of view, identify possible interventions, examine alternatives, and reflect on the process so that the learning model can have a good impact to help students in dealing with their mathematical problems (LaForce et al., 2017; Yew \& Goh, 2016).

Based on the results of previous research, it is known that the Problem Based Learning model has a good impact on helping students to improve mathematical thinking skills (Tarmizi \& Bayat, 2012), effective in learning (Alkhasawneh et al., 2008), and learning can be student-centered (Park \& Ertmer, 2007). In addition, the PBL model also encourages 
students to make good decisions by encouraging students to identify sources that will assist in data collection and decision making (Surya \& Syahputra, 2017). However, there has been no research related to the application of the PBL model to higher-order critical thinking skills. This is important to do to overcome the low level of higher-order thinking skills of students.

Based on the explanation above, this paper aims to fill research gaps related to the application of the PBL model to improve students' critical thinking skills. In addition, students' initial abilities and mathematical beliefs also need to be seen how much influence they have on students' higher-order thinking skills.

\section{METHODS}

This research is quasi-experimental research with a non-equivalent control group design. The experimental and control group were selected randomly. The authors obtained two classes to be used as research samples, each of which became an experimental class (applied PBL model) and control class (applied conventional learning model). The treatment was given for four weeks, starting with giving a learning outcome test that was useful for dividing the sample into groups of initial ability (high and moderate) and a questionnaire to divide the sample into the mathematical belief group (high and low). It should be noted that apart from differences in learning models, there is no other treatment that is different, including the same tasks, media, and topics taught. After that, a post-test was given as reference data to see the effect of each treatment on higher-order mathematical thinking skills.

The population in this research were students of SMP Negeri 27 Jakarta. The research samples consisted of 7 classes and totaled 165 students. The sample has been tested for normality and homogeneity using SPSS 25 software with the provision of sig. $>5 \%$. The research instrument is an essay test that is used to measure higher-order mathematical thinking skills and a mathematical belief questionnaire. Before the test instrument is given, it is first tested to determine the level of validity, reliability, level of difficulty, and discriminatory index. From the validity and reliability test, this instrument is declared valid and reliable and has good distinguishing power and level of difficulty. The students' initial ability data uses the data from the last exam results on the sample that has been owned by the teacher. The mathematical belief questionnaire is used to classify students with high and low mathematical beliefs. Hypothesis testing in this research used a three-way ANOVA test, which had previously been tested for normality and homogeneity. The description of the steps for implementing the PBL model which is thought to be able to increase student learning activities is presented in Figure 1.

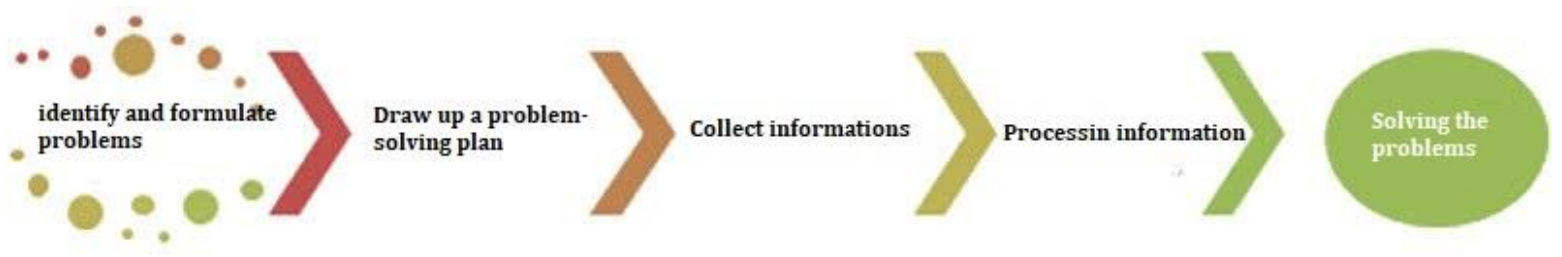

Figure 1. Problem Based Learning Process 


\section{RESULTS AND DISCUSSION}

\section{Descriptive Statistics}

The research data used for analysis are in the form of initial mathematical ability test (IMA) data, mathematical belief, and the result scores of higher-order mathematical thinking skills (HOTS) which are treated with Problem Based Learning and conventional learning models.

Table 1. Comparison of Descriptive Statistics Scores of Higher-Orders Mathematical Thinking Ability (HOTS) of Each Group of Students Based on Treatment, IMA, and Mathematical Belief

\begin{tabular}{|c|c|c|c|c|c|c|c|c|}
\hline \multirow{3}{*}{$\begin{array}{c}\text { Descriptive } \\
\text { Statistics }\end{array}$} & \multicolumn{4}{|c|}{ Conventional } & \multicolumn{4}{|c|}{ Problem Based Learning } \\
\hline & \multicolumn{2}{|c|}{ Low IMA } & \multicolumn{2}{|c|}{ High IMA } & \multicolumn{2}{|c|}{ Low IMA } & \multicolumn{2}{|c|}{ High IMA } \\
\hline & $\begin{array}{l}\text { Low } \\
\text { Belief }\end{array}$ & $\begin{array}{l}\text { High } \\
\text { Belief }\end{array}$ & $\begin{array}{c}\text { Low } \\
\text { Belief }\end{array}$ & $\begin{array}{l}\text { High } \\
\text { Belief }\end{array}$ & $\begin{array}{c}\text { Low } \\
\text { Belief }\end{array}$ & $\begin{array}{l}\text { High } \\
\text { Belief }\end{array}$ & $\begin{array}{l}\text { Low } \\
\text { Belief }\end{array}$ & $\begin{array}{l}\text { High } \\
\text { Belief }\end{array}$ \\
\hline Total & 17 & 16 & 24 & 11 & 16 & 13 & 11 & 26 \\
\hline Min & 34.13 & 18.13 & 33.75 & 37.25 & 24.75 & 35.25 & 37.25 & 31.38 \\
\hline Max & 73.50 & 83.25 & 83.25 & 93.75 & 79.00 & 80.13 & 86.00 & 93.75 \\
\hline Average & 47.29 & 47.63 & 55.30 & 62.58 & 49.15 & 59.60 & 66.14 & 67.48 \\
\hline
\end{tabular}

Briefly, the description in Table 1 shows that at the same level of initial mathematical ability (IMA) and mathematical belief, the higher-order mathematical thinking ability (HOTS) scores of students who received problem-based learning model treatment are higher than students who received conventional learning models. However, further testing will be carried out in the following discussion to obtain research objectives.

\section{Data Analysis Prerequisite Test}

The comparison of the increased scores in students' higher-order mathematical thinking skills (HOTS) can be seen by testing the hypothesis using the Analysis of Variance (ANOVA) and t-test. Before testing the hypothesis, the data analysis requirement tests are carried out which include the normality and homogeneity tests.

Testing the normality of the data after the treatment aims to determine the normality of the class data that has been studied. The normality test was carried out using the Lilliefors test at a significance level of $\alpha=0.05$ with the help of SPSS software. The data used is the score of the higher-order mathematical thinking ability (HOTS) based on the treatment group, initial mathematical ability (IMA), and mathematical belief.

Normality test is done by testing the following hypothesis:

$\mathrm{H}_{0} \quad$ : Data is normally distributed

$\mathrm{H}_{1} \quad$ : Data is not normally distributed

$\alpha=0.05$

Test Statistics : P-value or Sig. Value on the results of the Lilliefors Test

Critical Area $: \mathrm{H}_{0}$ is rejected if $\mathrm{P}$-value or Sig. Value $<\alpha(0.05)$

The results of the data normality test for higher-order mathematical thinking ability (HOTS) test scores based on the treatment group, initial mathematical ability (IMA), and mathematical belief can be seen in Table 2 . 
Table 2. Higher-Order Mathematical Thinking Ability Score (HOTS) Normality Test

\begin{tabular}{|c|c|c|c|c|}
\hline \multirow{2}{*}{ HOTS Normality Test } & \multicolumn{4}{|c|}{ Shapiro Wilk Test - Lilliefors Significance Correction } \\
\hline & Statistic & df & Sig & Conclusions \\
\hline \multicolumn{5}{|c|}{ Based on the Treatment of Learning Model } \\
\hline Conventional & 0.973 & 68 & 0.148 & Data is normally distributed \\
\hline Problem Based Learning & 0.977 & 66 & 0.271 & Data is normally distributed \\
\hline \multicolumn{5}{|c|}{ Based on Initial Mathematics Ability (IMA) } \\
\hline Low IMA & 0.971 & 62 & 0.151 & Data is normally distributed \\
\hline High IMA & 0.972 & 72 & 0.104 & Data is normally distributed \\
\hline \multicolumn{5}{|c|}{ Based on Mathematical Belief } \\
\hline Low Mathematical Belief & 0.967 & 68 & 0.072 & Data is normally distributed \\
\hline High Mathematical Belief & 0.976 & 66 & 0.229 & Data is normally distributec \\
\hline
\end{tabular}

Table 2 shows the data on the higher-order mathematical thinking ability (HOTS), both based on the treatment of the learning model, initial mathematical ability (IMA), as well as mathematical belief, all of which have met the prerequisites for a normal distribution.

Meanwhile, the homogeneity of variance test is carried out with the following hypothesis:

$$
\begin{array}{ll}
\mathrm{H}_{0}: \sigma_{1}{ }^{2}=\sigma_{2}{ }^{2} & \mathrm{H}_{1}: \sigma_{1}{ }^{2} \neq \sigma_{2}{ }^{2} \\
\alpha=0.05 &
\end{array}
$$

Test Statistics : P-value or Sig. Value on the results of the Fisher - Levene Test

Critical Area $: \mathrm{H}_{0}$ is rejected if :

P-value or Sig. Value $<\alpha(0.05)$

The results of the homogeneity of variance test for higher-order mathematical thinking ability (HOTS) scores based on the treatment group, initial mathematical ability (IMA), and mathematical belief can be seen in Table 3 .

\begin{tabular}{|c|c|c|c|c|c|}
\hline \multirow[b]{2}{*}{ HOTS Group } & \multicolumn{5}{|c|}{ Shapiro Wilk Test - Lilliefors Significance Correction } \\
\hline & $\begin{array}{l}\text { Levene } \\
\text { Statistic }\end{array}$ & df1 & df2 & Sig & Conclusions \\
\hline $\begin{array}{l}\text { Learning Model } \\
\text { Treatment }\end{array}$ & 0.001 & 1 & 132 & 0.973 & \multirow{3}{*}{$\begin{array}{c}\text { The variance of the two groups of data is } \\
\text { homogeneous }\end{array}$} \\
\hline $\begin{array}{c}\text { Initial Mathematical } \\
\text { Ability (IMA) }\end{array}$ & 0.001 & 1 & 132 & 0.973 & \\
\hline Mathematical Belief & 2.827 & 1 & 132 & 0.095 & \\
\hline
\end{tabular}

Table 3. Higher-Order Mathematical Thinking Ability Score (HOTS) Normality Test

Table 3 shows the homogeneity test of the data variance of higher-order mathematical thinking ability (HOTS) in each group of students based on the treatment of learning models, initial mathematics ability (IMA), and mathematical belief, all of which show a homogeneous variance.

After the analysis prerequisite test is fulfilled, then the next step is to test the effect of learning model treatment on higher-order mathematical thinking skills (HOTS) in terms of initial mathematical ability (IMA) and mathematical belief, which was carried out using the ANOVA test on the $2^{3}$ factorial design method. 


\section{Hypothesis Testing - Three-Way ANOVA $2^{3}$ Factorial Design}

Hypothesis testing will be carried out using analysis of variance (ANOVA) to see the effect of treatment, initial mathematical ability (IMA), and mathematical belief as well as the interaction of each of these variables on the higher-order mathematical thinking ability (HOTS) scores. After that, it will be continued with a t-test to determine the effect of the learning model treatment on the higher-order mathematical thinking ability (HOTS) scores in each group of initial mathematics ability (IMA) and mathematical belief.

Before testing the difference in Higher-Order Mathematical Thinking Ability (HOTS) scores between learning model treatments using the ANOVA table, an F test will be carried out first to see in general whether there is an effect of each factor, including the interaction between factors.

Hypothesis testing on the $\mathrm{F}$ test as follows:

$H_{0}: \beta_{1}=\beta_{2}=\beta_{3}=\beta_{12}=\beta_{13}=\beta_{23}=\beta_{123}=0, \quad H_{1}$ : There is at least $1 \beta \neq 0$

Test Statistics : P-value or Sig. Value on the results of the ANOVA Test

Critical Area $\quad: \mathrm{H}_{0}$ is rejected if: P-value or Sig. Value $<\alpha(0.05)$

The summary table of the ANOVA test results can be seen in Table 4 using the F test to investigate whether there is an effect of each factor, including the interaction between factors.

Table 4. Summary of ANOVA Test Results on the Effect of Learning Model Treatment, Initial Mathematical Ability (IMA), Mathematical Belief and Their Interaction on Higher-Order Mathematical Thinking Ability (HOTS)

\begin{tabular}{|c|c|c|c|}
\hline No. & Hypothesis & $\begin{array}{c}\text { Test } \\
\text { Results }\end{array}$ & Conclusions \\
\hline 1 & $\begin{array}{l}\text { Differences in HOTS based on } \\
\text { Learning Model Treatment }\end{array}$ & $\begin{array}{l}\mathrm{H}_{0} \text { is } \\
\text { Rejected }\end{array}$ & $\begin{array}{l}\text { There is a difference in HOTS scores between } \\
\text { conventional learning model and problem-based } \\
\text { learning model }\end{array}$ \\
\hline 2 & $\begin{array}{l}\text { Differences in HOTS based on Initial } \\
\text { Mathematics Ability (IMA) }\end{array}$ & $\begin{array}{c}\mathrm{H}_{0} \text { is } \\
\text { Rejected }\end{array}$ & $\begin{array}{l}\text { There is a difference in HOTS scores between } \\
\text { low and high IMA students }\end{array}$ \\
\hline 3 & $\begin{array}{l}\text { Differences in HOTS based on } \\
\text { Mathematics Belief }\end{array}$ & $\begin{array}{l}\text { Failed to } \\
\text { Reject } \mathrm{H}_{0}\end{array}$ & $\begin{array}{l}\text { There is no difference in HOTS scores between } \\
\text { low and high Mathematics Belief students }\end{array}$ \\
\hline 4 & $\begin{array}{l}\text { The difference in HOTS because the } \\
\text { interaction between the learning } \\
\text { model treatment and the initial ability } \\
\text { of mathematics (IMA) }\end{array}$ & $\begin{array}{l}\text { Failed to } \\
\text { Reject } \mathrm{H}_{0}\end{array}$ & $\begin{array}{l}\text { There is no difference in the HOTS score } \\
\text { because of the interaction factor between the } \\
\text { treatment of the learning model and IMA }\end{array}$ \\
\hline 5 & $\begin{array}{l}\text { The difference in HOTS because the } \\
\text { interaction between the learning } \\
\text { model treatment and the Mathematical } \\
\text { Belief }\end{array}$ & $\begin{array}{l}\text { Failed to } \\
\text { Reject } \mathrm{H}_{0}\end{array}$ & $\begin{array}{l}\text { There is no difference in the HOTS score } \\
\text { because of the interaction factor between the } \\
\text { treatment of the learning model and the } \\
\text { Mathematical Belief }\end{array}$ \\
\hline 6 & $\begin{array}{l}\text { Differences in HOTS based on the } \\
\text { Treatment of Learning Models in } \\
\text { Groups of Students with Low IMA }\end{array}$ & $\begin{array}{l}\text { Failed to } \\
\text { Reject } \mathrm{H}_{0}\end{array}$ & $\begin{array}{l}\text { In the group of students with low IMA, there is } \\
\text { no difference in HOTS scores between students } \\
\text { who received conventional learning models and } \\
\text { students who received problem-based learning } \\
\text { models }\end{array}$ \\
\hline 7 & $\begin{array}{l}\text { Differences in HOTS based on the } \\
\text { Treatment of Learning Models in } \\
\text { Groups of Students with High IMA }\end{array}$ & $\begin{array}{l}\mathrm{H}_{0} \text { is } \\
\text { Rejected }\end{array}$ & $\begin{array}{l}\text { In the group of students with high IMA, there is } \\
\text { a difference in HOTS scores between students } \\
\text { who receive conventional learning models and } \\
\text { students who receive problem-based learning } \\
\text { models }\end{array}$ \\
\hline
\end{tabular}




\begin{tabular}{|c|c|c|c|}
\hline No. & Hypothesis & $\begin{array}{c}\text { Test } \\
\text { Results }\end{array}$ & Conclusions \\
\hline 8 & $\begin{array}{l}\text { Differences in HOTS based on the } \\
\text { Treatment of Learning Models in } \\
\text { Groups of Students with Low } \\
\text { Mathematical Belief }\end{array}$ & $\begin{array}{l}\text { Failed to } \\
\text { Reject } \mathrm{H}_{0}\end{array}$ & $\begin{array}{l}\text { In the group of students with low Mathematical } \\
\text { Beliefs, there is no difference in the HOTS } \\
\text { scores between students who received } \\
\text { conventional learning models and students who } \\
\text { received problem-based learning models }\end{array}$ \\
\hline 9 & $\begin{array}{l}\text { Differences in HOTS based on the } \\
\text { Treatment of Learning Models in } \\
\text { Groups of Students with High } \\
\text { Mathematical Belief }\end{array}$ & $\begin{array}{c}\mathrm{H}_{0} \text { is } \\
\text { Rejected }\end{array}$ & $\begin{array}{l}\text { In the group of students with high Mathematical } \\
\text { Beliefs, there is a difference in HOTS scores } \\
\text { between students who receive conventional } \\
\text { learning models and students who receive } \\
\text { problem-based learning models }\end{array}$ \\
\hline
\end{tabular}

Table 4 shows which factors have a significant influence on the Higher-Order Mathematical Thinking Ability (HOTS) score. There are 4 (four) things that affect the Higher-Order Mathematical Thinking Ability (HOTS) scores, namely:

1. The difference in the treatment of learning models (conventional learning models and problem-based learning) affects the Higher-Order Mathematical Thinking Ability (HOTS) scores of students.

2. The differences in Students' Initial Mathematical Ability (IMA) affect students' Higher-Order Mathematical Thinking Ability (HOTS) scores.

3. In the group of students with high IMA, there are differences in HOTS scores between students who receive conventional learning models and students who receive problem-based learning models.

4. In the group of students with high Mathematical Beliefs, there is a difference in HOTS scores between students who receive conventional learning models and students who receive problem-based learning models.

The results of data analysis both descriptively and by statistical testing showed that students who received the problem-based learning model had higher-order mathematical thinking ability (HOTS) scores that were higher than the higher-order mathematical thinking ability (HOTS) score of students who received the conventional learning model. In accordance with its understanding, this higher-order mathematical thinking ability (HOTS) has 4 (four) aspects, namely, mathematical communication, mathematical reasoning, mathematical connection, and mathematical problem-solving. To be able to fulfill higherorder mathematical thinking skills (HOTS), certainly, an alternative learning model is needed that includes the four aspects mentioned above. The problem-based learning model is an alternative learning method that uses an approach in which students are faced with authentic and meaningful problems as a starting point for gaining or integrating new knowledge. The problem-based learning model that is applied has a positive influence on students' higherorder mathematical thinking skills (HOTS). It is as mentioned by Alkhasawneh et al., (2008) that the problem-based learning model makes students more effective in teaching and learning activities. Contradictory thing mentioned by (Park \& Ertmer, 2007), which stated that the PBL model does not significantly change students' beliefs in using technology. However, the pattern of learning that was originally teacher-centered turned into student-centered.

Furthermore, the results of data analysis both descriptively and by statistical testing also showed that students with the high initial mathematical ability (IMA) had higher higher-order 
mathematical thinking ability (HOTS) scores than low initial mathematical ability (IMA). This is in line with the research results of Lestari (2017) and Hevriansyah \& Megawanti, (2017) which stated that the initial mathematical ability in the high category has better learning outcomes than students with low initial ability. Students' initial abilities are abilities, backgrounds, and characteristics that students already have before participating in learning which can be measured by giving a pre-test or pre-requisite test. In learning mathematics, mathematical concepts are arranged hierarchically, structured, logically, and systematically starting from the simplest concepts to the most complex concepts. This concept is important to be able to increase the meaningfulness of learning, which in turn has an impact in facilitating the internal processes that take place in students when learning. Initial mathematical ability (IMA) can be defined as the initial prerequisite ability or the basic ability of students which is an image of student readiness as well as a provision for students to receive mathematics learning materials with higher concepts. Initial mathematical ability (IMA) has an influence on students' higher-order mathematical thinking skills (HOTS). Initial mathematical abilities can be a student's initial provision for students to receive mathematics learning materials with higher concepts.

The results showed that for students with high mathematical beliefs, the higher-order mathematical thinking ability (HOTS) scores of students who received the problem-based learning model are higher than students who received the conventional learning model. Students with high mathematical beliefs have a high preference for the discipline of mathematics which is needed in formulating mathematical ideas to solve mathematical problems. Therefore, problem-based learning can be a solution for teachers in implementing learning models in the classroom.

\section{CONCLUSIONS}

The results of the research can be summarized into three things, namely: 1) Problem-based learning models have a better effect on students' higher-order thinking skills than conventional learning classes that teachers usually use; 2) students with high initial ability have higher-order thinking skills better than students with low initial abilities; 3) students with high mathematical beliefs have higher-order thinking skills better than students with low mathematical belief. Based on this, it can be concluded that problem-based learning is good for use in the classroom in improving students' mathematical thinking skills.

This research can be further developed to see the effect of problem-based learning on other mathematical abilities. For educators, it can also observe students' confidence in mathematics in the learning process.

\section{AUTHOR CONTRIBUTIONS STATEMENT}

DAS conceptualized the idea and prepare research designs. MA presents research data and data calculations. WR composes abstract and the conclusions reached.

\section{REFERENCES}

Abdullah, A. H., Mokhtar, M., Abd Halim, N. D., Ali, D. F., Tahir, L. M., \& Kohar, U. H. A. (2016). Mathematics teachers' level of knowledge and practice on the implementation of 
higher-order thinking skills (HOTS). Eurasia Journal of Mathematics, Science and Technology Education, 13(1), 3-17.

Albay, E. M. (2019). Analyzing the effects of the problem solving approach to the performance and attitude of first year university students. Social Sciences \& Humanities Open, 1(1), 100006.

Alkhasawneh, I. M., Mrayyan, M. T., Docherty, C., Alashram, S., \& Yousef, H. Y. (2008). Problem-based learning (PBL): Assessing students' learning preferences using VARK. Nurse Education Today, 28(5), 572-579.

Astriani, L. (2017). Pengaruh pembelajaran reciprocal teaching terhadap kemampuan pemahaman konsep matematika ditinjau dari kemampuan awal matematika siswa. FIBONACCI: Jurnal Pendidikan Matematika dan Matematika, 3(1), 77-85.

Astuti, S. P. (2015). Pengaruh kemampuan awal dan minat belajar terhadap prestasi belajar fisika. Formatif: Jurnal Ilmiah Pendidikan MIPA, 5(1).

Firmansyah, M. A. (2017). Peran kemampuan awal matematika dan belief matematika terhadap hasil belajar. Prima: Jurnal Pendidikan Matematika, 1(1), 55-68.

Hadi, S., Retnawati, H., Munadi, S., Apino, E., \& Wulandari, N. F. (2018). The difficulties of high school students in solving higher-order thinking skills problems. Problems of Education in the 21st Century, 76(4), 520.

Heong, Y. M., Yunos, J. M., Othman, W., Hassan, R., Kiong, T. T., \& Mohamad, M. M. (2012). The needs analysis of learning higher order thinking skills for generating ideas. Procedia-Social and Behavioral Sciences, 59, 197-203.

Hevriansyah, P., \& Megawanti, P. (2017). Pengaruh kemampuan awal terhadap hasil belajar matematika. JKPM (Jurnal Kajian Pendidikan Matematika), 2(1), 37-44.

Hwang, J., Choi, K. M., \& Hand, B. (2020). Examining domain-general use of reasoning across science and mathematics through performance on standardized assessments. Canadian Journal of Science, Mathematics and Technology Education, 20(3), 521-537. Scopus.

Isharyadi, R. (2017). Pengaruh mathematical beliefs terhadap prestasi belajar matematika siswa SMA. PYTHAGORAS: Journal of the Mathematics Education Study Program, 6(1), Article 1.

LaForce, M., Noble, E., \& Blackwell, C. (2017). Problem-based learning (PBL) and student interest in STEM careers: The roles of motivation and ability beliefs. Education Sciences, 7(4), 92.

Lestari, W. (2017). Pengaruh kemampuan awal matematika dan motivasi belajar terhadap hasil belajar matematika. Jurnal Analisa, 3(1), 76-84.

Majeed, B. H., Jawad, L. F., \& Salim ALRikabi, H. T. (2021). Tactical thinking and its relationship with solving mathematical problems among mathematics department students. International Journal of Emerging Technologies in Learning, 16(9).

Nurmantoro, M. A. (2017). Pengaruh kemampuan awal, kecerdasan emosi dan motivasi belajar terhadap kemampuan komunikasi matematis siswa. Prosiding Diskusi Panel 
Pendidikan, 1(1), 1-11.

Park, S. H., \& Ertmer, P. A. (2007). Impact of problem-based learning (PBL) on teachers' beliefs regarding technology use. Journal of Research on Technology in Education, 40(2), 247-267.

Purbaningrum, K. A. (2017). Kemampuan berpikir tingkat tinggi siswa smp dalam pemecahan masalah matematika ditinjau dari gaya belajar. JPPM (Jurnal Penelitian Dan Pembelajaran Matematika), 10(2).

Purwaningrum, D., \& Sumardi, S. (2016). Efek strategi pembelajaran ditinjau dari kemampuan awal matematika terhadap hasil belajar matematika kelas XI IPS. Manajemen Pendidikan, 11(2), 155-167.

Ramadhan, S., Sunarto, D. M., \& Prasetyo, Z. K. (2020). Higher order thinking skill in physics; A sistimatical review. Thinking, 29(5), 5102-5112.

Rittle-Johnson, B., \& Schneider, M. (2015). Developing conceptual and procedural knowledge of mathematics. Oxford Handbook of Numerical Cognition, 1118-1134.

Seibert, S. A. (2021). Problem-based learning: A strategy to foster generation Z's critical thinking and perseverance. Teaching and Learning in Nursing, 16(1), 85-88.

Seman, S. C., Yusoff, W. M. W., \& Embong, R. (2017). Teachers challenges in teaching and learning for higher order thinking skills (HOTS) in primary school. International Journal of Asian Social Science, 7(7), 534-545.

Surya, E., \& Syahputra, E. (2017). Improving high-level thinking skills by development of learning pbl approach on the learning mathematics for senior high school students. International Education Studies, 10(8), 12-20.

Syarifah, L. L. (2017). Pengaruh model pembelajaran dan belief matematika terhadap kemampuan komunikasi matematis. AlphaMath: Journal of Mathematics Education, 2(2), Article 2.

Syarifah, L. L., \& Firmansyah, M. A. (2016). Pengaruh model pembelajaran learning cycle terhadap kemampuan komunikasi matematis siswa dengan belief matematika. Seminar Nasional Matematika Dan Pendidikan Matematika UNY, 8, 1-8.

Tanudjaya, C. P., \& Doorman, M. (2020). Examining higher order thinking in indonesian lower secondary mathematics classrooms. Journal on Mathematics Education, 11(2), 277-300.

Tarmizi, R. A., \& Bayat, S. (2012). Collaborative problem-based learning in mathematics: A cognitive load perspective. Procedia-Social and Behavioral Sciences, 32, 344-350.

Volk, M., Cotič, M., Zajc, M., \& Starcic, A. I. (2017). Tablet-based cross-curricular maths vs. Traditional maths classroom practice for higher-order learning outcomes. Computers \& Education, 114, 1-23.

Yew, E. H., \& Goh, K. (2016). Problem-based learning: An overview of its process and impact on learning. Health Professions Education, 2(2), 75-79. 